\title{
JAPANESE SUPPOSITIONAL ADVERBS: PROBABILITY AND STRUCTURE IN SPEAKER-HEARER INTERACTION
}

\section{INTRODUCTION}

From the point of view of discourse, modal meanings are interesting because, although their expression is structurally bound to sentences, their scope tends to converge with discourse units in conversation. In spoken Japanese, up to about $10 \%$ of suppositional modality meanings seem to be expressed by the seemingly redundant combination of the SUPPOSITIONAL ADVERB (suiryooteki hukusi) and some corresponding UTTERANCE FINAL MODALITY FORM as in (1) below.

$$
\text { ... dooyara [kono mati ni mo gonin gurai wa ( } i)-r u] \text { rasii-] } \ldots
$$
somehow this town at too five_persons about WA are -RU it_seems (WA=CONTRAST; -RU=NONPAST-AFFIRMATIVE; brackets denote structural layers) Somehow, it seems as if there should be about five [of them] in this town, too.

This redundancy is not limited to combinations of suppositional, or more widely, modal adverbs and the sentence-final modality form alone. It is common with other adverbs as, for example, adverbs modifying restrictive particles, as below:

$$
\begin{aligned}
& \text {...tatta muttu-no seibun dake... } \\
& \text { just six -of ingredients only } \\
& \text {...no more than just six ingredients... [internet commercial] }
\end{aligned}
$$

It seems to be widespread in Japanese.

This study is limited to the suppositional modality in Japanese and is concerned with the discourse aspects of this particular way of expression in spoken Japanese. By examining the effects of such redundancy on speaker $(\mathrm{S})$ - hearer $(\mathrm{H})$ interaction it attempts to elucidate what motivates the emergence of this "quasi-grammatical" (c.f. Kudô 2000) relationship between suppositional adverbs and sentence-final modality forms.

The methodology of the study is based on the view of language phenomena as essentially probabilistic, with structural aspects emerging from continuously repeated linguistic interaction. Study is empirically oriented, being based on the analysis of spoken Japanese corpora.

In the research of speaker hearer interaction, the contribution of case and topic particles (Tanaka 2000) as well as the contribution (among other factors) of modal

* Author's address: Filozofska fakulteta, Oddelek za azijske in afriške študije, Aškerčeva 2, 1000 Ljubljana, Slovenia. Email: andrej.bekes@guest.arnes.si 
adverbs (Szatrowski 2002) towards syntactic projection has been pointed out. As has been shown also by Szatrowski (ibid. 319-320) the combination of a suppositional adverb and an utterance final modality form facilitates syntactic projection and thus the prediction of the incoming discourse.

On the other hand, empirical studies (c.f. Kudô 2000), TABLE 1 in the Appendix, show that the range and likelihood of sentence final modality forms co-occurring with suppositional adverbs vary considerably from adverb to adverb.

It is therefore possible to make a conjecture that the degree of predictability of some particular sentence final modality forms is commensurate with the frequency of its co-occurrence with some suppositional adverbs.

The present study has two goals: to examine this conjecture and to pinpoint a possible motivation for such redundant co-occurrences. Two corpora of spoken Japanese, Oikawa's (1998) formal interview corpus and Ohso's (2003) spontaneous informal conversation corpus, will be used for this purpose.

\section{CO-OCCURRENCES OF SUPPOSITIONAL ADVERBS AND SENTENCE FINAL MODALITY FORMS}

\subsection{Means employed to express suppositional modality in conversation}

Suppositional modality in conversation data can be expressed in different ways and the semantically redundant co-occurrence of the modal adverb with the utterance final modality form is one of the several possibilities. As a shorthand to distinguish the different types more easily, A will be used for the MODAL ADVERB, $M$ for the UTTERANCE FINAL MODALITY FORM, $P$ for the predication in between, and $\varnothing$ when neither A nor $\mathrm{M}$ were expressed explicitly. Based on this convention, the following types can be distinguished. First, the example (1) above illustrates the semantically redundant utterance type A-P-M. Other basic types are illustrated in (3) below:
(3) $\mathrm{a}^{*} \quad$ zyuuhati dewa-nai $\boldsymbol{n}$-zyanaika, ...
[utterance type Ø-P-M]
18 is-not EXPECTED

[She] is not 18 , I would say.

b I.Z.-mo issyo-ni kita desyoo ne..., tabun [utterance type P-M-A]

I.Z.-also together came POSSIBILITY TAG likely

Probably, I.Z. did not come together either, did she.

c

...tabun, daizyoobu ø

[utterance type A-P-Ø]

...likely, all right $\quad$ COPULA $=\varnothing$

[It is] probably all right.

d tabun, ne

[utterance type A]

likely, TAG

Perhaps, isn't it.

$\begin{array}{ll}\text { e desyoo, } & n e \\ \text { POSSIBILITY } & \text { TAG }\end{array}$

[utterance type M]

Perhaps, isn't it.

*(Examples a-e are from the Nagoya University Japanese Conversation Corpus, Ohso 2003.) 
Indeed, modal adverbs and utterance final modality forms do co-occur quite often, but the overall picture is more complex. The majority of utterances have modality expressed only by the utterance final modality form, as in (3)a. These are the utterances of type Ø-P-M (no modal adverb, and a predication and utterance final modality form M). Often, the modal adverb is added as an afterthought, as in (3)b. These are the utterances of type P-M-A (i.e., predication, utterance final modality M and modal adverb A).

Or, it is modal adverb alone providing the specific modality, as in (3)c, with the utterance final modality form being omitted or just expressing a general assertion (a subtype of A-P-Ø). Finally, there are cases where only modality is asserted, either with the modal adverb alone, as in (3)d (utterance type A), or with the utterance final modality form alone, as in (3)e (utterance type M). In (3), the type of each utterance is indicated in square brackets on the right side.

\subsection{Co-occurrences of $A$ and $M$ in the utterances of type $A-P-M$}

Kudô (ibid.) made a detailed analysis of co-occurrences of suppositional adverbs with sentence final modality forms on a large corpus of written language data (about 100 million characters). The co-occurrence frequencies are given in TABLE 1 in the Appendix. As can be seen from the table, suppositional adverbs fall roughly into the four groups that correlate in their co-occurrences with the four types of suppositional modality.

Following Kudô, co-occurrences of suppositional adverbs and sentence final modality forms were tabulated for the conversation data in the Oikawa (1998) corpus. Oikawa (1998) is a corpus of 50 interviews in Japanese, with interviewers and interviewees being native Japanese speakers.

Tabulated co-occurrences are shown in TABLE 2 in the Appendix. Since Kudô has been working with written data and since the size of the Oikawa (1998) data are about $1 \%$ of the data used by Kudô, Kudô's set of suppositional adverbs is larger and also includes all the suppositional adverbs found in Oikawa. Spoken data, as there is less time for planning, thus reflect a less complex picture than written data.

\subsection{Structural and probabilistic view of "modal adverb - utterance-final modality form pair"}

In corpus linguistics, systematically co-occurring forms are analyzed as collocations. In this sense, modal adverb - utterance final modality form co-occurrences are also collocations, though this does not concern neighboring elements but collocations over a long distance.

Another way of looking at them is as bracket-like structures (c.f. Bekeš 2007). Structurally, in each particular sentence, they actually bracket off the scope of the particular modality being expressed. For example, in example (1), the scope of the particular suppositional modality, bracketed by the adverb dooyara (somehow) and the sentence final modality form rasii (it seems) is kono mati ni mo gonin gurai wa ( $i$ ) $-r u$ (there should be about five [of them] in this town, too). Thus, this structure can be seen as a means to reduce the indeterminacy of the information that is 
conveyed by the speaker to the hearer. The speaker wishes to mark the scope of modality explicitly. From the speaker's point of view (and also from the ex-post fact analysis), it is indeed possible to speak of an A-M pair (e.g. dooyara - rasii in (1)) as a bracket, delimiting the scope of modality in a deterministic sense.

On the other hand, from the hearer's point of view, the appearance of the modal adverb itself triggers the conditional probabilities of utterance final modality forms or types that tend to co-occur with the initial modal adverb. On the basis of these probabilities, the hearer is able to restrict the range of possibilities of interpretation and thus process the incoming information more efficiently. Thus, from the hearer's perspective, the A-M pair is a binary Markoff chain (c.f. Manning and Schütze 1999): with any given modal adverb, the utterance final modality form appears with certain conditional probability ascribed to their co-occurrence.

\subsection{Hypothesis}

The above observations regarding the probabilistic aspect of the bracket structure hold only in the utterances of the type A-P-M where the modal adverb A provides advance clues to the hearer. An example where a particular adverb is only weakly associated with some modality forms is the adverb doomo ('somehow', see TABLE 2), which, co-occurring in similar frequencies with many different types of modality forms, can only vaguely signal what modality form is going to appear at the end of the utterance.

On the other hand, there are adverbs such as tabun ('probably', co-occurring in TABLE 2 with the modality type EXPECTED 32 times out of 41, i.e., in $78 \%$ of all cases), which can be a strong predictor of the utterance-final modality type, and thus of understanding the whole relevant segment as belonging to this modality type even before the completion of the utterance. This observation forms the basis of the hypothesis (4) below:

(4) Hypothesis

In Speaker-Hearer interactions, in utterances of the type A-P-M, the Adverb Modality form combinations with a higher co-occurrence probability will enable the hearer to better predict the scope of some particular modality as well as the timing of the relevant incoming predicate, as compared to the Adverb Modality form combinations with lower co-occurrence probabilities.

The canonical position of the utterance modality form in Japanese is after the predicate.

In this respect, the layered structure of the Japanese sentence (cf. Minami 1993) is an important clue, as has been argued by Szatrowski (2002). The problem is that quite often conversational data which are not well structured in this respect are encountered. An example of such data is (5) in the next section. 


\section{SPEAKER-HEARER INTERACTION: HEARER'S INTERVENTIONS}

In conversation, speakers and hearers tend to cooperate. During the conversation, the hearer may intervene in various ways, by aizuti tags, co-constructions and turns. Various examples of such interventions are shown in (5), a segment of an interview, $\mathrm{P}$ being the interviewer and $\mathrm{Y}$ the interviewee. The hearer's interventions are shown in [].

(5) Y:/etto, sensei ga ossyatta hutatume no

[P:hai yes] ano, koyuu no,

[P:un yeah] katati o sorezore no, tiiki de

[P:ee yeah] mezasiteiru katte iu,

[P:un,un yeah, yeah] situmon ni mazu okotaesuru to,

[P:ee yeah] TABUN zyoohoo mo,

[P:un yeah] moo sekaizyuu, sugu ni nagareru,

[P:un yeah] syakai desu node,

[P:soo desu yo nee right, of course] ano daitai ugoki

to iuka nagare to site wa,

[P:uun yeah] / anoo, / dandan issyowell,

[P:un yeah], ni natte ikutte iu ka koo,

[P:un yeah] /ko, koyuu no, bunkatte iu ka,

[P:aaa, dakara boodaresu ni, natteiku to

yeah, therefore, by becoming border-less], ee,

[P:kentiku no of architecture] usuretei/kulyoona

[P:unun yeah, yeah] Lki ga surun desukeredomo.

P:naruhodo nee, uunI see, yeah... well, the second thing that you said well, in particular...

the form, in each of the regions

[that they are] striving at,

let me answer [this] question first

PROBABLY the information, as well

is already flowing everywhere in the world

because [it is such a] society

well, the movement, or shall I say

trends

getting together more and more

or how should I say, thus...

should I say the particular cultures

yeah

are getting dimmer and dimmer

it seems to be [like that]...

Example (5) is interesting because the section spoken by $\mathrm{Y}$ is syntactically poorly structured: the only structure that clearly stands out seems to be the modal adverb utterance final modality form relationship. It seems that in poorly structured utterances in spontaneous speech, A - M bracket structures serve secondarily as an important means of organizing the spoken text and thus facilitating the hearer's perception of it.

There are various types of aizuti tags used in (5). For example, shorter expressions such as hai ('yes'), signaling that the hearer is following what is being said.

Then, there are longer interventions, showing still deeper involvement, such as aaa, dakara boodaresu ni, natteiku to ('yeah, therefore, by becoming border-less...'), where the hearer is making his or her own conclusions on the basis of what has been said, but without taking the turn permanently. In the Oikawa data, the co-constructions were not marked explicitly at the point at which they occurred. It is therefore not clear whether some interventions, such as the last one, could be classified as co-constructions or not. Finally, there is an example of the hearer taking a turn as the next speaker at the end of (5). 
Because of the small size of the corpus, individual types of interventions were not frequent enough to guarantee a statistically meaningful observation. Therefore, in order to achieve a statistically sufficient number of cases, different types of the hearer's interventions such as aizuti tags, putative co-constructions and turn-taking were all merged under the common label 'INTERVENTION', which will be used in the remainder of this paper.

\section{ANALYSIS}

In the hypothesis (4), a higher frequency of co-occurrence was proposed to be a clue to the hearer's better prediction of the scope of modality and thus of the timing of the predicate. It is expected that hearer's prediction is based on the experience-based conditional probability of the sentence final modality form (or of the sentence final modality type) co-occurring with a given modal adverb. To proceed further, it is necessary to estimate the hearer's experience-based probabilities of such co-occurrences.

\subsection{Empirical estimate of co-occurrence probabilities}

The totality of verbal exchange of an individual up to a given point in time can be viewed as a kind of corpus. Thus an estimate of co-occurrence probabilities could be achieved by analyzing a corpus of comparable size. The size of the spoken corpora used here (Oikawa 1998 and Ohso 2003) is too small (see TABLE 2 for Oikawa corpus), and the frequencies of the majority of relevant co-occurrences too low to provide a meaningful estimate. On the other hand, the frequencies obtained by Kudô from the written corpus are high enough to warrant meaningful estimates. The size of the corpus data used by Kudô is by itself already comparable to the amount of language data exchange in several years' worth of conversation. Judging from the similarities and dissimilarities of the frequency distribution in TABLE 1 and TABLE 2, the main difference is that some of the co-occurrences, which are less frequent in spoken data (TABLE 2), tend to be more frequent in written data (TABLE 1). On the other hand, the reverse case, i.e. frequent co-occurrences in spoken data being less frequent in written data, does not seem to be true. If it is additionally considered that the majority of people nowadays absorb a considerable amount of linguistic input in its written form, then, lacking a better alternative (such as 100 million word spoken corpus), the frequencies obtained by Kudô will be taken as viable estimates for the present study.

But even in Kudô's data it is necessary to agglomerate the individual A-M co-occurrences into co-occurrences of adverbs with forms belonging to one of the following four suppositional modality types, i.e., NECESSITY, EXPECTED, CONJECTURE and POSSIBILITY.

Co-occurrence probability estimates for those adverb - modality type pairs that are attested in the conversation data are shown in the TABLE 3 in the Appendix. It is interesting to observe that the estimated probabilities fall neatly into two distinct groups. In the group HIGH, there are co-occurrences with the estimated probability 
equal or higher than $50 \%$ and in the group LOW, co-occurrences with the probability lower than $10 \%$. Group HIGH displays one order of the magnitude (5-20 times) larger probabilities than group LOW - a fact that is possibly related to "statistical markedness" (c.f. Halliday 1991). An exception is kanarazu ('certainly'), whose empirical probability of co-occurring with NECESSITY is $13 \%$. Since this is reasonably close to the rest of the group LOW, kanarazu is also included in the group LOW for the purpose of this study. This inclusion does not impair the results. The reason is that since according to the hypothesis, a higher co-occurrence probability would result in a better prediction of the scope of modality, the inclusion of kanarazu which has a relatively high co-occurrence probability among the LOW group would only affect the prediction adversely.

Thus the divided combinations of adverbs and modality types displayed 74 occurrences in the group HIGH and 32 occurrences in the group LOW. In TABLE 3 , for each adverb - modality type combination, the number of co-occurrences and the probability group (LOW or HIGH) is shown on the right side of the table.

\subsection{Sentence-final modality type and the hearer's interventions}

Considering that the estimates of the co-occurrence probabilities of adverb sentence final modality type are ready, it is possible to proceed to test the hypothesis (5).

According to the hypothesis, A-P-M type combinations with a higher co-occurrence probability will enable the hearer to better predict the scope of some particular modality and thus the timing of the incoming predicate in comparison to low co-occurrence probability cases.

Expecting that a hearer is cooperating, it is reasonable to suppose that the timing of his or her interventions would tend to coincide with breaks in the flow of the speaker's conversation. Since a stretch of the speaker's conversation displaying a particular modality provides such segmentation, the hearer's ability to predict the type of sentence-final modality and thereby also its location would result in a larger frequency of the hearer's interventions in the immediate vicinity of the predicate as compared with the lower co-occurrence probability cases.

This conjecture has been tested in the TABLE 4 below.

TABLE 4: Coincidence of the hearer's interventions in the vicinity of co-occurring utterance final modality form

\begin{tabular}{|c|c|c|c|}
\hline $\begin{array}{c}\text { Probability of } \\
\text { co-occurrence }\end{array}$ & $\begin{array}{c}\text { Number of A-P-M } \\
\text { type of utterances }\end{array}$ & \multicolumn{2}{|c|}{$\begin{array}{c}\text { Position of H's intervention relative to pred- } \\
\text { icate forms and the number of interventions }\end{array}$} \\
\hline & & $\begin{array}{c}\text { Immediately before } \\
\text { P to before M }\end{array}$ & $\begin{array}{c}\text { Coinciding with } \mathrm{M} \\
\text { or after M }\end{array}$ \\
\hline LOW & 32 & $4(12.5 \%)$ & $28(87.5 \%)$ \\
\hline HIGH & 74 & $20(27.0 \%)$ & $54(73.0 \%)$ \\
\hline
\end{tabular}


The 'Immediate vicinity of the predicate' means the position immediately before the predicate or coinciding with the predicate up to just before the modality form ("Immediately before $\mathrm{P}$ to before $\mathrm{M}$ " in the table), and coinciding with or after the modality form ("Coinciding with $\mathrm{M}$ or after $\mathrm{M}$ " in the table).

In the case when an intervention can occur concurrently with or after the utterance final modality form, then interventions due to prediction and ex post facto judgment at the end of the bracket cannot be distinguished and were therefore left out of consideration. Thus, only those cases when an intervention occurred in the position ranging from immediately before the predicate up to the beginning of the modality form were considered. These interventions should more likely be due to the hearer's hypothetical prediction of the modality form type. If this were indeed the case, then the proportion of interventions in this position for the LOW group should be expected to be lower than the proportion of interventions at the same position in the HIGH group.

This is illustrated below in (6), which is actually the last part of example (5). Here the relevant interventions are marked with an asterisk and precede the predicate in speaker Y's utterance.

[P:un yeah], ni natte ikutte iu ka koo, [P:un yeah] /ko, koyuu no, bunkatte iu ka,

* [P:aaa, dakara boodaresu ni, natteiku to yeah, therefore, by becoming border-less], * [P:kentiku no of architecture] usuretei/kulyoona [P:unun yeah, yeah] $/ k i$ ga surun desukeredomo. P:naruhodo nee, uunI see, yeah... or how should I say, thus... should I say the particular cultures

$e e$, yeah

are getting dimmer and dimmer it seems to be [like that]...

Oikawa (1998)

The timing of the first intervention, a co-construction type, [P:aaa, dakara boodaresu ni, natteiku to yeah, therefore, by becoming border-less] may not only be due to the hearer's prediction of the predicate alone, but perhaps also to Y's hesitation ee in this transcription immediately following the intervention, while possibly uttered at more or less the same time, may have also have been a clue. Hearer P's second, shorter intervention, also of the co-construction type, [P:kentiku no of architecture] follows the speaker's hesitation $e e$, and immediately precedes the predicate + modality form usuretei[kuJyoona in speaker Y's utterance. On the other hand, the intervention immediately following the modality form yoona (seems as) in Y's utterance does not count as an intervention based on prediction since the possibility that the preceding modality form may have been the trigger cannot be excluded. The same is also true of the first P's utterance after the turn-taking took place, i.e., P: naruhodo nee, uun (I see, yeah...), since it happened after the modality of the Y's utterance has been fully expressed.

As can be seen in TABLE 4, for the interventions occurring at the position ranging from immediately before the predicate to the modality form, the proportion 
of interventions (\%) belonging to the LOW group (12.5\%) and to the HIGH group (27.0\%) differ, with the proportion belonging to the LOW group being lower than predicted by the hypothesis.

As the total number of observed cases is low, it turns out that this result shown in TABLE 4 seems to be only weakly significant statistically $(\mathrm{p}<0.1)$ according to the "comparison of proportions" test (Walpole 1974: 178). Commonsense significance is usually taken as $\mathrm{p}<0.05$.

\section{DATA FROM THE NAGOYA UNIVERSITY JAPANESE CONVERSATION CORPUS}

For a better understanding, another corpus (Nagoya University Japanese Conversation Corpus, NUJCC, Ohso 2003) was also analyzed. In this corpus, the co-occurrences of the type A-P-M were about 5 times less frequent than in Oikawa corpus. The data were too small to test them statistically.

Their scarcity opens a question regarding the role of A-M and other bracket-like forms in conversation in relation to the type of discourse. Both corpora differ in many significant aspects, presented in the TABLE 5 below.

TABLE 5: Principal differences between the Oikawa (1998) and NUJCC data

\begin{tabular}{|l|l|l|}
\hline Differences & Oikawa (1998) & NUJCC \\
\hline Setting & Formal & Informal \\
\hline S-H familiarity & Unfamiliar & Familiar \\
\hline S-H status similarity & Different, Hierarchical & Similar \\
\hline Degree of shared knowledge & Low & High \\
\hline
\end{tabular}

The conversations in the Oikawa corpus are interviews: the interviewer is usually a professor and the interviewees graduate students. The setting is formal since the interviewer and interviewee are usually not familiar with each other. There is a very low degree of sharing knowledge pertinent to the topics of conversation.

On the other hand, the conversations in NUJCC are between family members and intimate friends, mostly in informal settings, with a high degree of shared background knowledge.

The differences between the two corpora are also reflected in the differences in the register of modal adverbs, as can be seen in TABLE 6 below. To make the frequencies of the use of various suppositional adverbs comparable, the counts were modified by the size of each corpus, shown in the table as frequency per $1 \mathrm{MB}$ of data (freq./1 MB). As would be expected, the adverbs belonging to less formal register are more common in the NUJCC data and more formal adverbs are more common in the Oikawa data. 
TABLE 6: Differences in register (NUJCC vs. Oikawa)

\begin{tabular}{|l|c|c|c|}
\hline Adverbs & $\begin{array}{c}\text { NUJCC } \\
\text { freq./1MB }\end{array}$ & $\begin{array}{c}\text { Oikawa } \\
\text { freq./1MB }\end{array}$ & $\begin{array}{c}\text { NUJCC : Oikawa } \\
\text { proportion }\end{array}$ \\
\hline kitto & $\mathbf{4 9 . 1}$ & $\mathbf{1 3 . 4}$ & $\mathbf{3 . 6 9}$ \\
\hline kanarazu & 14.3 & 28.0 & 0.51 \\
\hline osoraku & 2.6 & 9.8 & 0.27 \\
\hline tabun & $\mathbf{1 6 4 . 6}$ & $\mathbf{5 4 . 9}$ & $\mathbf{3 . 0 0}$ \\
\hline taitei & 1.4 & 12.2 & 0.11 \\
\hline doomo & $\mathbf{2 2 . 6}$ & $\mathbf{8 . 5}$ & $\mathbf{2 . 6 6}$ \\
\hline yoppodo & $\mathbf{9 . 7}$ & $\mathbf{2 . 4}$ & 4.04 \\
\hline mosikasitara & 9.4 & 14.6 & 0.64 \\
\hline hyottositara & 1.1 & 1.2 & 0.91 \\
\hline kanarazusimo-nai & 2.3 & 4.9 & 0.47 \\
\hline angai & 4 & $\mathbf{1 . 2}$ & 3.33 \\
\hline
\end{tabular}

There is a very clear difference between the demands faced by the participants in these different situations. The interviews had no possibility to rely on the hearer's prior sharing of background information and there were also setting and status differences. This would entail the need for a more explicit, elaborate presentation of information, closer to what Givón (1979) would call the "syntactic mode".

In the NUJCC corpus, there was a large degree of shared knowledge and mutual familiarity as well as the informal setting and proximity in status, and so the demands on both participants were much less, resulting in a very elliptic discourse, akin to Givón's (ibid.) "pragmatic mode". Examples in (3) are an illustration of such types of conversation. The overall picture is subsumed in the TABLE 7 below.

TABLE 7: Mutual position of the Oikawa and NUJCC data on the "pragmatic mode - syntactic mode continuum" (c.f. Givón 1979)

\begin{tabular}{|c|c|c|c|}
\hline \multirow{2}{*}{$\begin{array}{c}\text { TIGHT FORMAL } \\
\text { ORGANIZATION }\end{array}$} & \multicolumn{3}{|c|}{} \\
\hline \multirow{1}{*}{$\uparrow$} & WRITTEN & syntactic mode & $\begin{array}{c}\text { Kudô } \\
(2000) \text { data }\end{array}$ \\
\cline { 2 - 4 } & SPOKEN-FORMAL & tighter pragmatic mode & $\begin{array}{c}\text { Oikawa } \\
\text { data }\end{array}$ \\
\cline { 2 - 4 } & $\begin{array}{c}\text { SPOKEN-INFORMAL/ } \\
\text { FAMILI AR }\end{array}$ & $\begin{array}{c}\text { looser pragmatic } \\
\text { mode }\end{array}$ & $\begin{array}{c}\text { NUJCC } \\
\text { data }\end{array}$ \\
\hline $\begin{array}{c}\text { LOOSE FORMAL } \\
\text { ORGANIZATION }\end{array}$ & \multicolumn{3}{|c}{} \\
\hline
\end{tabular}


The fact that the bracket-like A-P-M type utterances are present in Oikawa corpus and much less in NUJCC data conforms with the conjecture that an explicit signaling of the scope of modality reduces the indeterminacy and thus helps the hearer to process the incoming discourse more efficiently. Indeed, the unfamiliar participants in interviews face a higher degree of indeterminacy in their interviews than close friends or family members do in their everyday small talk, which is reflected in the more frequent use of A-P-M type of utterances.

\section{CONCLUSION}

The two corpora have been examined to verify the predictions of the hypothesis (4), namely that predictable combinations of suppositional adverbs with sentence final modality types reduce the indeterminacy in discourse and may thus influence the speaker-hearer interaction as reflected in the timing of the hearer's interventions.

The analysis has shown that 1) the A-P-M type of expressing modality in utterances is more common in contexts requiring a higher precision (i.e. less indeterminacy) in communication, as reflected in the Oikawa corpus of formal interviews compared to the Ohso corpus of informal conversations. And 2) that in such contexts, there seems to be a better perception of more probable co-occurrences of modal adverbs with utterance final modality, as reflected in the timing of the hearer's interventions and coinciding with the immediate vicinity of the predicate.

Because the A-P-M type of utterances also appears in informal conversations, albeit much less frequently, it can be supposed that besides the sociolinguistic and pragmatic factors mentioned in section 4 , the other more discourse specific factors governing the use of the A-P-M type of utterances could also be at play. These factors should be sought in the direction of prominence and the connection of such prominence with the hearer's specific local needs and the speaker's goals in particular discourses.

On the other hand, using the A-M bracket structure as a predictor of incoming discourse, as seems to be the case in more formal contexts, it can be thought of as a secondary development. The high probabilities in the co-occurrence of certain adverbs with certain utterance final modal forms ("quasi grammatical" in Kudô's words) can be seen to be a result of a gradual process of amplification, thus providing a glimpse into the process of structure emerging from high co-occurrence probabilities.

Because of the small size of corpora used in this study, the above results will have to be tested on larger size corpora, which have become available recently. Also, the role that the A-P-M type of utterances play in the context, other than reducing indeterminacy, will have to be examined in more detail in the future.

The result obtained here may also provide an additional substantiation for the observation made by Szatrowski (2002), i.e., that the high predictability of the utterance final modality forms does contribute to more frequent co-constructions. In the present study, all aizuti tags, co-construction, and turn-taking were merged under the label of 'interventions'. Due to the different nature of these interventions, the differences in their timing and their dependence on the prediction are likely to 
appear. For the finer estimates regarding the types of interventions, a re-examination of the present study on a larger corpus of conversational data is necessary.

The role that experience-based probabilities could play may also have important repercussions for Japanese language teaching and related research.

Finally, other types of bracket structures should also be examined to see how the different types of bracket structures contribute not only to disambiguating but also to predicting the incoming discourse.

\section{Notes}

1. An earlier version of this paper was presented at "The third conference on Japanese language and Japanese language teaching", Rome, 17-19th March, 2005.

2. This study has been supported by the research program of the Languages and Cultures of Asia and Africa (grant No. P6-0243-0581-04), Ministry of Higher Education of Slovenia. Parts of it were completed during my stay as a JSPS visiting research fellow at the University of Tsukuba (June-July 2005) and as a visiting research fellow at the Nagoya University Graduate School of International Development (November 2005-March 2006). To all these institutions I would like to express my sincere gratitude.

\section{Literature}

BEKEŠ, Andrej (2007) "Boundary as a functional domain: with special reference to the usage of particle WA in narrative". In: Paolo Calvetti/Silvana De Maio (eds.), Proceedings of the Second Conference on Japanese Linguistics and Language Teaching. Naples, March 20th-22nd, 2002 (U. N. O., Vol. 71). Napoli: Università degli studi di Napoli "L'orientale". Dipartimento di Studi Asiatici, Associazione italiana didattica lingua giapponese, Instituto italiano per L'Africa e L'Oriente, The Japan Foundation, 1-26.

BEKEŠ, Andrej (2006) "Japanese suppositional adverbs in speaker-hearer interaction". In: Aldo Tollini (ed.), The third conference on Japanese language and Japanese language teaching. Proceedings of the conference, Rome, 17-19th March, 2005. Venice: Cafoscarina, 34-48.

BEKEŠ, Andrej (in print) "Pragmatics of 'boundary marking' in Japanese texts with special reference to WA-topic and modal adverbs." Proceedings from the Journée de linguistique japonaise à Paris 7, October 30, 2004, University Paris 7.

Givón, Talmy (1979) On understanding grammar. New York: Academic Press.

HallidaY, Michael A.K. (1991) "Corpus studies and probabilistic grammar". In: Karin Aijmer/Bengt Altenberg (eds.), English corpus linguistics: studies in honor of Jan Svartvik. London: Longman, 30-43.

HoPPER, Paul (1988) "Emergent grammar and the apriori grammar postulate". In Deborah Tannen (ed.), Linguistics in context. Collected general lectures from the 1985 LSA Linguistic Institute, Georgetown University. Norwood, NJ: Ablex, 117-134.

Hopper, Paul J./Elizabeth C. Traugott (1993) Grammaticalization. Cambridge: Cambridge University Press. 
KuDô, Hiroshi (2000) "Fukushi to bun no chinjutsutekina taipu (adverbs and the sentence enunciation type)." In: Yoshio Nitta/Takashi Masuoka (eds), Nihongo no bunpô 3: modaritii (Japanese grammar 3: modality). Tokyo: Iwanami shoten, 161-234.

MACWHINNEY, Brian (2001) "Emergentist approaches to language." In Joan Bybee/Paul Hopper (eds.), Frequency and the emergence of linguistic structure. Amsterdam: John Benjamins, 449-470.

MANnING, Christopher D./Hinrich SchÜTZE (1999) Foundations of Statistical Natural Language processing. Cambridge, Massachusetts: The MIT Press.

Minami, Fujio (1993) Gendai nihongo bunpô no rinkaku (outline of the modern Japanese grammar). Tokyo: Taishûkan shoten.

SzATROWSKI, Polly (2002) "Syntactic projectability and co-participant completion in Japanese conversation". Berkeley Linguistic Society 28, 315-325.

TANAKA, Haruko (2000) Turn-taking in Japanese conversation: a study in grammar in interaction. Amsterdam: John Benjamins.

Walpole, Ronald E. (1974) Introduction to statistics. New York: MacMillan Publishing Co.

\section{Corpora}

Corpus I: OıKawa, Terufumi (1998) Jinbunkagaku to kopyûtâ DATABASE vol. 1, Sôgô kenkyû daigaku.(Transcribed interviews by 50 Japanese native speakers. Unfamiliar participants, systematic status differences. Text file size $0.82 \mathrm{MB}$ ).

Corpus II: OHso, Mieko (2003) Meidai kaiwa kôpasu. Kagakukenkyûhi kiban kenkyu (B)(2) Nihongogakushûjisho hensan ni muketa denshika kôpasu riyô ni yoru korokeeshon kenkyû (2001-3). (Nagoya University Japanese Conversation Corpus /NUJCC/. Unpublished research report. About 100 informal conversations between familiar participants. Text file size $3.5 \mathrm{MB}$ ). 


\section{Appendix}

TABLE 1: Co-occurrences of A and M (Kudoo 2000:204, Table 3.1)

\begin{tabular}{|c|c|c|c|c|c|c|c|c|c|c|c|c|c|c|c|c|c|}
\hline $\begin{array}{r}\text { PREDICATE } \\
\text { FORM }\end{array}$ & 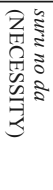 & 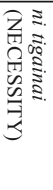 & 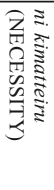 & 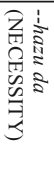 & 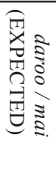 & 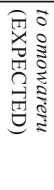 & 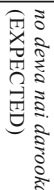 & 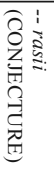 & 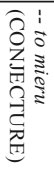 & 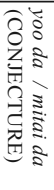 & 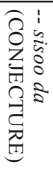 & 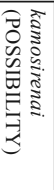 & 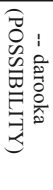 & 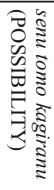 & 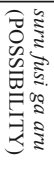 & $\stackrel{\overrightarrow{0}}{\overrightarrow{0}}$ & 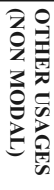 \\
\hline \multicolumn{18}{|l|}{ ADVERB } \\
\hline kitto'surely' & 139 & 38 & 8 & 3 & 66 & 12 & & & & 1 & 4 & 8 & & & & 279 & 85 \\
\hline kanarazu 'certainly' & 17 & 5 & 2 & 1 & 11 & & & & & & & & & & & 36 & 146 \\
\hline zetttai(ni)'absolutely' & 48 & & & & & & & & & & & & & & & 48 & 38 \\
\hline osoraku'probably' & 31 & 18 & & 1 & 112 & 5 & 10 & 2 & & 1 & & 2 & & & & 182 & -- \\
\hline tabun'likely' & 19 & 1 & & 2 & 74 & & 1 & 1 & & & 2 & 3 & & & & 103 & -- \\
\hline sazo'surely' & & & & & 52 & & 1 & & & & 1 & & & & & 54 & -- \\
\hline ookata'probably' & 2 & 1 & & & 24 & & 1 & & & & & & & & & 28 & 13 \\
\hline taitei'usually' & 3 & & & 1 & 7 & & & & & & & & & & & 11 & 80 \\
\hline taigai'mostly' & 2 & & & & 4 & & & & & & & & & & & 6 & 33 \\
\hline dooyara'somehow' & 5 & & & & & & 1 & 29 & & 10 & & & & & 1 & 46 & 39 \\
\hline doomo'somehow' & 13 & 1 & & & & & 6 & 24 & & & & 1 & & & & 45 & 385 \\
\hline $\begin{array}{c}\text { yohodo -yoppodo } \\
\text { 'very' }\end{array}$ & 6 & 2 & & & 7 & & 2 & 12 & 9 & 3 & & & 2 & & & 43 & 150 \\
\hline aruiwa'perhaps' & & & & & 3 & 2 & 4 & & & & & 53 & 3 & 1 & & 66 & 69 \\
\hline mosikasureba'maybe' & 2 & & & 1 & 1 & 1 & 11 & & & & & 30 & & & & 46 & -- \\
\hline hyottositara'possibly' & 2 & & & & & & 7 & & & & & 16 & 1 & & & 26 & -- \\
\hline $\begin{array}{l}\text { kotoniyoruto 'possi- } \\
\text { bly' }\end{array}$ & 1 & & & & & & 4 & & & & & 7 & 1 & 1 & & 14 & -- \\
\hline angai'fairly' & & 1 & & & 1 & & 3 & 1 & & & 1 & 8 & & & & 15 & 81 \\
\hline
\end{tabular}


TABLE 2: Co-occurrences of A and M (Oikawa 1998)

\begin{tabular}{|c|c|c|c|c|c|c|c|c|c|c|c|c|c|c|}
\hline $\begin{array}{l}\text { SENTENCE FINAL } \\
\text { MODAL ITY FORM }\end{array}$ & 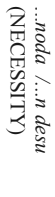 & 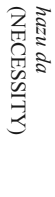 & 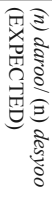 & 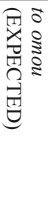 & 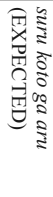 & 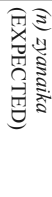 & 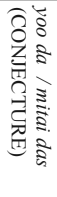 & 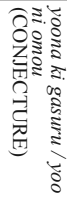 & 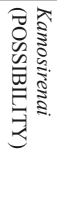 & 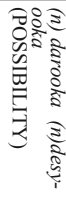 & 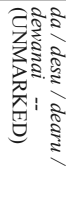 & 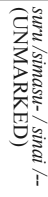 & $\overrightarrow{0}$ & 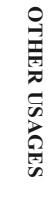 \\
\hline \multicolumn{15}{|l|}{ ADVERBS } \\
\hline kitto & & & 3 & 4 & 1 & & & & 1 & & & & 9 & \\
\hline kanarazu & 1 & 1 & & 2 & & & & & & & 4 & 7 & 15 & \\
\hline osoraku & 2 & & 1 & & & 3 & & & & & 1 & 1 & 8 & \\
\hline tabun & 2 & & 2 & 26 & & 4 & 1 & & 1 & & 4 & 1 & 41 & 4 \\
\hline ookata & & & & & 1 & & & & & & & & 1 & \\
\hline taitei & 1 & & & 1 & & 1 & & & & & 2 & 3 & 8 & 1 \\
\hline doomo & 1 & & & & & 1 & & 2 & & & & 3 & 7 & 1 \\
\hline yohodo-yoppodo & 1 & & & & & & & & & & & & 1 & \\
\hline aruiwa & & & & & & & & & & & & & & 12 \\
\hline mosikasitara & & & 1 & & & 1 & & & 5 & 1 & & 1 & 9 & 3 \\
\hline hyottositara & & & & & & & & & & & & 1 & 1 & \\
\hline kanarazusimo...nai & & & & & & & & & 1 & & 4 & & 5 & \\
\hline angai & & & & & & 1 & & & & & & & 1 & \\
\hline
\end{tabular}


TABLE 3: Suppositional adverbs: empirical probability of co-occurrence with particular modality types and the frequency of co-occurrences in Oikawa data (based on Kudô 2000:204, Table 3.1)

\begin{tabular}{|c|c|c|c|c|c|}
\hline ADVERB & MODALITY TYPE & \begin{tabular}{|c|} 
CO-OCCURRENCE \\
PROBABILITY: \\
HIGH-LOW
\end{tabular} & \begin{tabular}{|c|} 
EMPIRICAL PROB- \\
ABILITY OF \\
CO-OCCURRENCE
\end{tabular} & $\begin{array}{c}\text { FREQ. } \\
\text { HIGH }\end{array}$ & $\begin{array}{l}\text { FREQ. } \\
\text { LOW }\end{array}$ \\
\hline kitto & necessity & high & 0.52 & 9 & \\
\hline kanarazu & necessity & low & 0.13 & & 15 \\
\hline osoraku & expected & high & 0.7 & 8 & \\
\hline tabun & expected & high & 0.73 & 41 & \\
\hline ookata & expected & high & 0.6 & 1 & \\
\hline taitei & expected & low & $<0.1$ & & 8 \\
\hline doomo & conjecture & low & $<0.1$ & & 7 \\
\hline yohodo - yoppodo & conjecture & low & 0.12 & & 1 \\
\hline mosikasitara & possibility & high & 0.65 & 9 & \\
\hline hyottositara & possibility & high & 0.65 & 1 & \\
\hline kanarazusimo-nai & possibility & high & 0.5 & 5 & \\
\hline angai & possibility & low & $<0.1$ & & 1 \\
\hline \multicolumn{5}{|c|}{ Total number of high probability co-occurrences in Oikawa (HIGH) } & 74 \\
\hline \multicolumn{5}{|c|}{ Total number of low probability co-occurrences in Oikawa (LOW) } & 32 \\
\hline
\end{tabular}

Povzetek

\section{UGIBALNI PRISLOVI V JAPONŠČINI - VERJETNOST IN STRUKTURA V INTERAKCIJI MED GOVORCEM IN SOGOVORCEM}

Pričujoča študija se ukvarja $\mathrm{z}$ vlogo, ki jo v japonščini igra redundantno so-pojavljanje pomensko sorodnih modalnih prislovov (npr. tabun 'verjetno') $\mathrm{z}$ modalnimi formami na koncu povedi $\mathrm{v}$ interakciji med govorcem in sogovorcem. Temelječ na pogledu, da so takšna so-pojavljanja neke vrste probabilistične oklepajske strukture, je postavljena hipoteza, da tiste tovrstne oklepajske strukture, ki so predvidljive $\mathrm{z}$ večjo verjetnostjo, $\mathrm{s}$ tem, da pomagajo eksplicitno razmejiti območje dane modalnosti, z vidika sogovorca zmanjšujejo stopnjo nedoločnosti v diskurzu in tako prispevajo $\mathrm{k}$ večji učinkovitosti sporazumevanja. Podrobneje sta obravnavani dve napovedi hipoteze, najprej ta, da visoka verjetnost so-pojavljanja modalnih prislovov in modalnih form lajša sogovorčevo percepcijo modalnosti, ter druga, da je to povezano $\mathrm{z}$ stopnjo nedoločnosti $\mathrm{v}$ diskurzu. $\mathrm{Z}$ vidika so-pojavljanja ugibalnih modalnih prislovov z modalnimi formami na koncu povedi sta bila analizirana dva korpusa japonske konverzacije, eden, ki vsebuje intervjuje kot konverzacije med tujci v zelo formalnem kontekstu, kakršen ne dovoljuje nedoločnosti, ter drugi, ki ga sestavljajo pogovori prijateljev in družinskih članov v močno neformalnem okolju. Analiza je pokazala, da je 1) pogostost oklepajskih struktur tipa modalni prislov - modalna forma daleč pogostejša $v$ formalnem pogovoru med tujci ter da 2) v takih okoliščinah obstaja povezava $z$ boljšo percepcijo bolj verjetnih so-pojavljanj, ki se odraža v pogostejših intervencijah sogovorcev na relevantnih mestih $\mathrm{v}$ primerjavi z manj verjetnimi so-pojavljanji modalnih prislovov in modalnih form. 